\title{
Mass marking farmed Atlantic salmon with transgenerational isotopic fingerprints to trace farm fish escapees
}

\author{
Fletcher Warren-Myers ${ }^{1, *}$, Tim Dempster ${ }^{1}$, Per Gunnar Fjelldal ${ }^{2}$, Tom Hansen ${ }^{2}$, \\ Stephen E. Swearer ${ }^{1}$
}

\author{
${ }^{1}$ School of BioSciences, University of Melbourne, Parkville, Victoria 3010, Australia \\ ${ }^{2}$ Institute of Marine Research, Matre Aquaculture Research Station, 5984 Matredal, Norway
}

\begin{abstract}
Farmed fish sometimes escape and enter natural environments, where they mix with wild fish populations and can have negative effects. Marking farmed fish is a prerequisite for the identification of the origin of escapees and for guiding technical investigations to determine the cause of an escape event and improve farming practices. We tested transgenerational marking with enriched stable isotopes to assess its effectiveness as an accurate, feasible and cost-effective marking method for Atlantic salmon Salmo salar grown in sea-cage aquaculture. We injected a combination of 7 stable isotopes $\left({ }^{134} \mathrm{Ba},{ }^{135} \mathrm{Ba},{ }^{136} \mathrm{Ba},{ }^{137} \mathrm{Ba},{ }^{86} \mathrm{Sr},{ }^{87} \mathrm{Sr}\right.$ and $\left.{ }^{26} \mathrm{Mg}\right)$ at 4 different concentrations $\left(2,0.2,0.02\right.$ and $0.002 \mu^{-1} \mathrm{~g}^{-1}$ broodfish) into the abdominal cavity of female Atlantic salmon broodstock. Marking success was assessed in the otoliths of the resulting yolk sac larvae using laser ablation inductively coupled plasma mass spectrometry. Marking was $100 \%$ successful with $\mathrm{Ba}$ isotopes at concentrations as low as $0.002 \mu \mathrm{g}$ and for $\mathrm{Sr}$ isotopes at $2 \mu \mathrm{g}$, when at least 3 wk had passed between the day of injection and spawning. Our results demonstrate that 63 unique fingerprint marks can be made at a low cost using enriched isotopes of $\mathrm{Ba}$ (US\$0.0002-0.002 mark $^{-1}$ ) and Sr (US\$0.05-0.13 $\mathrm{mark}^{-1}$ ). Compared to other mass marking techniques, transgenerational marking of farmed salmon is an economically feasible method for tracing escapees with similarly low costs to delivery by egg bathing or vaccines, and an order of magnitude or more lower than other conventional marking methods.
\end{abstract}

KEY WORDS: Salmo salar · Barium · Otolith · Marking · Salmonids · Stock enhancement · Strontium

\section{INTRODUCTION}

The rise of modern industrial aquaculture has introduced millions of selectively bred fish into environments where they are co-located with wild conspecifics. When they escape from aquaculture facilities, farmed fish can cause damaging ecological impacts when mixing with wild fish (Fleming et al. 2000, McGinnity et al. 2003, Hindar et al. 2006, Hutchings \& Fraser 2008, Toledo-Guedes et al. 2012, Glover et al. 2013). Efforts to reduce escape events

${ }^{*}$ Corresponding author:

f.warren-myers@student.unimelb.edu.au first requires detection of where the escape event occurred, so that subsequent engineering investigations can determine the cause of the escape event and make recommendations to improve the technical standards of containment systems (Jensen et al. 2010).

Atlantic salmon Salmo salar escape from sea-cage aquaculture farms in every country in which they are produced. Detecting escaped farmed salmon once they become mixed within wild populations and tracing escapees back to their farm of origin remains

(C) The authors 2015. Open Access under Creative Commons by Attribution Licence. Use, distribution and reproduction are unrestricted. Authors and original publication must be credited. 
problematic. Although the point of escape can often be determined through DNA-based methods (Glover 2010), a fail-safe identification technique is still lacking. As an alternative to DNA-based approaches, a permanent tag or coded mark applied to all farmed fish would enable effective tracing. However, current mass marking methods, for example, fluorescent markers (Mohler 2003, Taylor et al. 2005), fin clipping and physical tags (Vander Haegen et al. 2005) or visible implant tags (FitzGerald et al. 2004), are unsuccessful with 1 or more aspects related to the ability to deliver $100 \%$ traceability to point of origin, fish welfare considerations or cost-effectiveness at industry scales.

Recently, new methods have been developed that enable $100 \%$ traceability of farmed salmon, are cost effective and have no impact on fish welfare throughout the production cycle. These methods involve the use of stable isotopes to code the otoliths of fish with unique isotope fingerprint marks during the hatchery stages of production (e.g. de-Braux et al. 2014, Warren-Myers et al. 2014, 2015a,b). To date, otolith marking with enriched stable isotopes of $\mathrm{Ba}$ and $\mathrm{Sr}$ has been highly successful in many species, and marks have been created using a range of delivery techniques, for example, via injection (Thorrold et al. 2006, Williamson et al. 2009b, Warren-Myers et al. 2014, 2015a), immersion (Munro et al. 2008, Woodcock et al. 2011b, de Braux et al. 2014, Warren-Myers et al. 2015b) or food supplementation (Woodcock et al. 2013).

The potential for identifying the origin of escaped farmed salmon with stable isotope marking is clear; between 7 and 63 mark combinations were created when Atlantic salmon parr were successfully marked with a combination of 6 isotopes mixed with a vaccine and delivered via injection (Warren-Myers et al. 2015a), and salmon embryos were marked with a combination of 3 isotopes during their egg-swelling phase immediately after fertilisation (Warren-Myers et al. 2015b). Another method with the potential to create additional multiple mark combinations with enriched stable isotopes in farmed salmon is transgenerational marking (Thorrold et al. 2006, Almany et al. 2007). This technique, which can successfully mark both freshwater (Munro et al. 2009, Starrs et al. 2014b) and marine fish species (Thorrold et al. 2006, Williamson et al. 2009b), requires an injection of enriched stable isotope into the abdominal cavity of mature females prior to spawning, which is then passed on in situ to the offspring. Marks are detectable in the core of otoliths of the resulting larvae (Thorrold et al. 2006). Many studies claim transgen- erational marking to be a successful technique for field applications to assess population connectivity (Thorrold et al. 2006, Williamson et al. 2009b, Huelga-Suarez et al. 2012), yet only 1 study (Almany et al. 2007) has demonstrated that transgenerational marking is feasible for mass marking tens to hundreds of females. In fish farming, transgenerational marking would allow all eggs of a single broodfish to be marked with a single injection several weeks prior to stripping and fertilisation. For hatcheries, this means that no extra labour or protocol steps would be required to mark fish from the day of stripping onwards. Marking prior to stripping may also be an advantage over marking during the egg-swelling (Warren-Myers et al. 2015b), larval (de Braux et al. 2014) or parr stages (Warren-Myers et al. 2015a), as it would ensure that all fish are marked prior to any movement of eggs or fish within or between hatcheries.

Past studies on transgenerational marking have shown that timing between spawning and injection and the concentration required for $100 \%$ marking success varies greatly among species. For example, concentrations of 0.5 to $23 \mu \mathrm{g} \mathrm{g}^{-1}$ female have been successful in saltwater species (Thorrold et al. 2006, Williamson et al. 2009b) and 0.3 to $40 \mu \mathrm{g} \mathrm{g}^{-1}$ female in freshwater species (Munro et al. 2009, HuelgaSuarez et al. 2013), with spawning occurring anywhere between 1 and $170 \mathrm{~d}$ post injection in freshwater species (Munro et al. 2009, Starrs et al. 2014 b) and 2 to $108 \mathrm{~d}$ in saltwater species (Cuif et al. 2014). Hence, the time between spawning and injection and the concentration required to achieve $100 \%$ marking success in farmed salmon requires optimisation to assess whether the technique will be suitable for large-scale application in aquaculture.

Here, we investigated whether transgenerational marking with enriched stable isotopes is a viable option for mass marking farmed Atlantic salmon by testing transgenerational marking on Atlantic salmon broodstock females using 7 enriched stable isotopes $\left({ }^{134} \mathrm{Ba},{ }^{135} \mathrm{Ba},{ }^{136} \mathrm{Ba}_{1}{ }^{137} \mathrm{Ba},{ }^{86} \mathrm{Sr},{ }^{87} \mathrm{Sr}\right.$ and $\left.{ }^{26} \mathrm{Mg}\right)$ at 4 concentrations $\left(2,0.2,0.02,0.002 \mu \mathrm{g} \mathrm{g}\right.$ broodfish $\left.^{-1}\right)$. We assessed marking success, mark strength and mark intensity in the otoliths of the resulting offspring. In addition, growth and mortality of offspring were monitored from hatching through to harvest size to check for any potential long-term effects of transgenerational marking with enriched stable isotopes. Finally, we provide cost estimates for the amount of isotope required to produce all successful fingerprint combinations. 


\section{MATERIALS AND METHODS}

\section{Experimental design}

The experiment was conducted at the Institute of Marine Research field station, at Matre, in Masfjorden, western Norway $\left(60^{\circ} \mathrm{N}\right)$ using Atlantic salmon broodfish (AquaGen strain) that had been transferred from sea-cages to onshore freshwater tanks buffered with saltwater to a salinity of $0.7 \mathrm{~g} \mathrm{NaCl} \mathrm{l}^{-1}$ 2 mo prior to the experiment. We tested transgenerational marking by injecting mature Atlantic salmon females (mean \pm SE mass: $9.15 \pm 0.26 \mathrm{~kg}$ ) in the abdominal cavity using a hypodermic syringe with a standard volume of $60 \mathrm{ml}$ prior to spawning. Each injection contained a combination of the enriched stable isotopes ${ }^{134} \mathrm{BaCl},{ }^{135} \mathrm{BaCl}_{1}{ }^{136} \mathrm{BaCl}_{1}{ }^{137} \mathrm{BaCl}$, ${ }^{86} \mathrm{SrCl},{ }^{87} \mathrm{SrCl}$ and ${ }^{26} \mathrm{MgCl}$ (Oak Ridge National Laboratory; www.ornl.gov) at 1 of 4 different enriched isotope concentrations or a $5 \% \mathrm{NaCl}$ (control) solution (Table 1). Females were checked once a week post injection for ripeness, and any females ready to spawn had their eggs stripped and a subsample of eggs fertilised with $2 \mathrm{ml}$ of sperm from 2 males $(1 \mathrm{ml}$ each).

Fertilised egg batches were kept at a constant temperature of $6^{\circ} \mathrm{C}$ throughout the egg incubation period (81 d) and yolk sac larval stage (52 d). Immediately prior to first feeding (Day 133), a subsample of 10 yolk sac larvae from each female's egg batch was collected and euthanized by anaesthetic overdose for otolith analysis. Sagittal otoliths from the subsampled larvae were dissected and removed, cleaned of any adhering tissue, air dried and stored individually in plastic tubes for otolith analysis. All remaining larvae from each egg batch were transferred to separate first feeding tanks, with a subsample of 50 fish from each batch randomly selected at the pre-smolt stage to be grown on to $4 \mathrm{~kg}$ harvest size.

Table 1. Stable isotope $\left({ }^{134} \mathrm{Ba},{ }^{135} \mathrm{Ba},{ }^{136} \mathrm{Ba},{ }^{137} \mathrm{Ba},{ }^{26} \mathrm{Mg},{ }^{86} \mathrm{Sr}\right.$, ${ }^{87} \mathrm{Sr}$ ) enrichment concentrations ( $\mu \mathrm{g} \mathrm{g}{ }^{-1}$ broodfish) used for transgenerational marking of Atlantic salmon Salmo salar $\left(\mathrm{n}=6\right.$ broodfish treatment ${ }^{-1}$ )

\begin{tabular}{|cc|}
\hline $\begin{array}{c}\text { Enriched isotope } \\
\text { concentration per treatment }\end{array}$ & $\begin{array}{c}\text { Treatment concentration } \\
\text { (total amount of isotope) }\end{array}$ \\
\hline 2 & 14 \\
0.2 & 1.4 \\
0.02 & 0.14 \\
0.002 & 0.014 \\
0 & 0 \\
\hline
\end{tabular}

\section{Otolith preparation}

Sagittal otoliths were cleaned as per WarrenMyers et al. (2014). Briefly, any remaining organic tissue was removed by immersing otoliths in a solution of ultrapure $15 \% \mathrm{H}_{2} \mathrm{O}_{2}$ buffered with $0.1 \mathrm{M}$ $\mathrm{NaOH}$. Following immersion, otoliths were ultrasonicated (Sonic Clean 250HT) for 5 min and then left for $6 \mathrm{~h}$ in the cleaning solution. The cleaning solution was then aspirated off and the otoliths were transferred through 3 Milli-Q water rinses, each of which consisted of $5 \mathrm{~min}$ of ultra-sonification and $30 \mathrm{~min}$ resting time. Otoliths were then air dried in a laminar flow bench for at least $24 \mathrm{~h}$. Once dry, 1 otolith fish ${ }^{-1}$ was fixed onto gridded microscope slides using quick dry cyanoacrylate glue. No polishing of otoliths was required prior to laser ablation.

\section{Otolith analysis}

Stable isotope analyses were done on a Varian 7700x inductively coupled plasma mass spectrometer (ICP-MS) fitted with a HelEx (Laurin Technic and the Australian National University) laser ablation (LA) system constructed around a Compex 110 (Lambda Physik) excimer laser operating at $193 \mathrm{~nm}$. National Institute of Standards and Technology (NIST) 612 and 610 glass standards doped with trace elements at known concentrations were used to calibrate the system. Otoliths were run in blocks of 16 samples selected randomly from all treatments and bracketed by analyses of the standards. External precision estimates (\% relative standard deviation) based on 20 analyses of NIST 612 and NIST 610 standards were as follows: NIST $612,{ }^{135} \mathrm{Ba}:{ }^{138} \mathrm{Ba}=0.38,{ }^{137} \mathrm{Ba}:{ }^{138} \mathrm{Ba}=$ $0.26,{ }^{86} \mathrm{Sr}:{ }^{88} \mathrm{Sr}=0.51,{ }^{87} \mathrm{Sr}:{ }^{88} \mathrm{Sr}=1.04$ and ${ }^{26} \mathrm{Mg}:{ }^{24} \mathrm{Mg}=$ 2.85; NIST $610,{ }^{134} \mathrm{Ba}:{ }^{138} \mathrm{Ba}=7.17$ and ${ }^{136} \mathrm{Ba}:{ }^{138} \mathrm{Ba}=$ 6.49. Samples and standards were analysed in timeresolved mode, using a spot size of $157 \mu \mathrm{m}$, a laser energy setting of $\sim 60 \mathrm{~mJ}$ and a laser repetition rate of $10 \mathrm{~Hz}$. Spot ablation was performed under pure $\mathrm{He}$ $\left(200 \mathrm{ml} \mathrm{min}^{-1}\right)$ to minimise re-deposition of ablated material and the sample was then entrained into the $\operatorname{Ar}\left(0.95 \mathrm{ml} \mathrm{min}^{-1}\right)$ carrier gas flow to the ICP-MS. Using this method, we were able to quantify the isotope ratios for ${ }^{134} \mathrm{Ba}:{ }^{138} \mathrm{Ba},{ }^{135} \mathrm{Ba}:{ }^{138} \mathrm{Ba},{ }^{136} \mathrm{Ba}:{ }^{138} \mathrm{Ba},{ }^{137} \mathrm{Ba}$ : ${ }^{138} \mathrm{Ba},{ }^{86} \mathrm{Sr}:{ }^{88} \mathrm{Sr},{ }^{87} \mathrm{Sr}:{ }^{88} \mathrm{Sr},{ }^{24} \mathrm{Mg}:{ }^{26} \mathrm{Mg}$ and ${ }^{55} \mathrm{Mn}:{ }^{43} \mathrm{Ca}$, from the edge to the core of each salmon yolk sac larval otolith using a single spot ablation $\left({ }^{55} \mathrm{Mn}:{ }^{43} \mathrm{Ca}\right.$ was used to identify when the laser had hit the core; Barbee \& Swearer 2007). Data were processed off-line using a specialised MS Excel template which in- 
volved a low pass filter to remove any spikes (a single acquisition value $>2 \times$ the median of the adjacent acquisitions), smoothing (a running average of 3 acquisitions) and blank subtracting functions. A correction factor ( $K=R_{\text {true }} / R_{\text {obs, }}$ where $R_{\text {true }}$ is the naturally occurring isotope ratio and $R_{\text {obs }}$ is the average isotope ratio measured in the NIST 612 or 610 standard run before and after each set of 16 samples) was applied to all sample acquisitions to correct for mass bias.

\section{Statistical analysis}

Marking success for each treatment (Fig. 1) was evaluated using a mark detection limit (Warren-

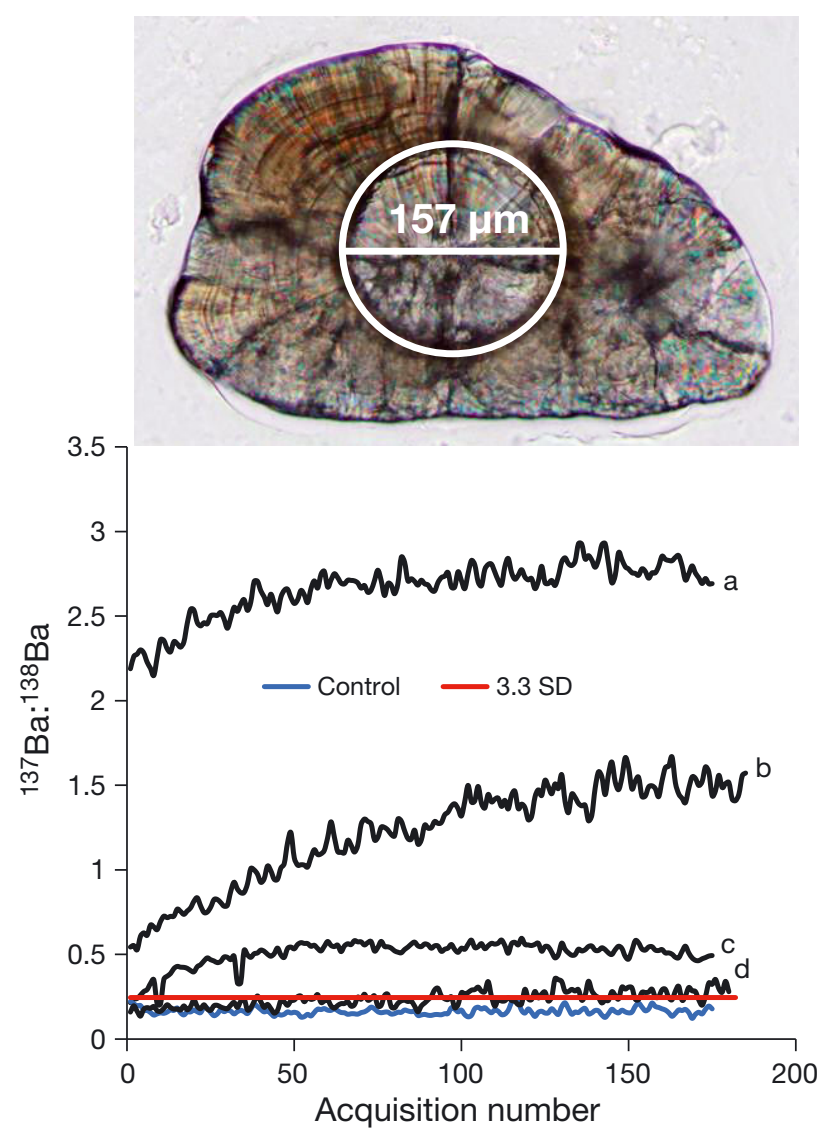

Fig. 1. Comparison of the change in ${ }^{137} \mathrm{Ba}:{ }^{138} \mathrm{Ba}$ between the otolith edge (acquisition no. $=0$ ) and core (acquisition no. 150-200) in marked yolk sac larval Atlantic salmon Salmo salar. Each black line represents an otolith marked with a different concentration of ${ }^{137} \mathrm{Ba}: \mathrm{a}=2, \mathrm{~b}=0.2, \mathrm{c}=0.02$ and $\mathrm{d}=0.002 \mu \mathrm{g} \mathrm{l}^{-1}$. The blue line represents a control fish, and the red line represents the mark detection limit, calculated as 3.3 standard deviations above the mean ratio measured in all control fish. A successful mark was classified as 3 consecutive acquisitions above the detection limit. Photo indicates the diameter of the laser spot size $(157 \mu \mathrm{m})$ used when ablating from the otolith edge (surface) to the core
Myers et al. 2014). Briefly, detection limits for the isotope ratios ${ }^{134} \mathrm{Ba}:{ }^{138} \mathrm{Ba},{ }^{135} \mathrm{Ba}:{ }^{138} \mathrm{Ba},{ }^{136} \mathrm{Ba}:{ }^{138} \mathrm{Ba}$, ${ }^{137} \mathrm{Ba}:{ }^{138} \mathrm{Ba},{ }^{86} \mathrm{Sr}:{ }^{88} \mathrm{Sr},{ }^{87} \mathrm{Sr}:{ }^{88} \mathrm{Sr}$ and ${ }^{26} \mathrm{Mg}:{ }^{24} \mathrm{Mg}$ were calculated from the average isotope ratios of all control fish (i.e. $0 \mu \mathrm{g} \mathrm{l}^{-1}$ treatment). To ensure a correct classification probability of $99.94 \%$, mark detection limits were set at 3.3 standard deviations (SDs) above the mean observed ratio in control fish for each enriched isotope used. Because of the inherent instability in isotopic ratios measured on single-detector, ICP-based mass spectrometers, we conservatively set the criteria for detecting a successful mark in the otolith as at least 3 consecutive acquisitions with ratios above the detection limit.

Mark strength and mark intensity for each enriched isotope used was analysed using 2-factor ANOVAs with isotope concentration and number of weeks between injection and spawning treated as fixed factors. An interaction term was not included, as 2 combinations of concentration by weeks post injection (Week 1, $0.002 \mu \mathrm{g}$ and Week 2, $2 \mu \mathrm{g}$ ) had no females spawn and hence no data. The response variables used were the mean maximum isotope ratio value (mark strength) and the mean proportion of acquisitions between the otolith edge and otolith core with ratio values above the detection limit (mark intensity) measured from the otoliths of the 10 subsampled fish for each egg batch. The effect of treatment on total hatchery mortality per egg batch and the number of larval deformities observed at first feeding per egg batch were analysed with 1-way ANOVAs. The effect of treatment on length, weight, Fulton's condition factor $(k)$ (Ricker 1975) and survival of harvest size fish was analysed with 1-way ANOVAs.

\section{RESULTS}

\section{Marking success}

Marking success was dependent on stable isotope enrichment concentration and the number of weeks between injection and spawning (Table 2). The highest concentration ( $2 \mu \mathrm{g} \mathrm{g}^{-1}$ fish) achieved $100 \%$ marking success in the shortest time period for the $\mathrm{Ba}$ (1 wk: ${ }^{134} \mathrm{Ba},{ }^{135} \mathrm{Ba}{ }^{136} \mathrm{Ba},{ }^{137} \mathrm{Ba}$ ) and Sr isotopes (3 wk: ${ }^{86} \mathrm{Sr},{ }^{87} \mathrm{Sr}$ ), but only $30 \%$ for ${ }^{26} \mathrm{Mg}$ by Week 3 . When the concentration was reduced (0.2 and $0.02 \mu \mathrm{g} \mathrm{g}^{-1}$ fish), $100 \%$ marking success for the Ba isotopes was achieved when spawning occurred at least $2 \mathrm{wk}$ post injection for ${ }^{135} \mathrm{Ba}$ and ${ }^{137} \mathrm{Ba}$, or at least $3 \mathrm{wk}$ post injection for ${ }^{134} \mathrm{Ba}$ and ${ }^{136} \mathrm{Ba}$. Marking success was poor for ${ }^{86} \mathrm{Sr}$, 
Table 2. Percentage of Atlantic salmon Salmo salar yolk sac larval otoliths marked using a combination of 7 enriched stable isotopes delivered via transgenerational marking. Marking success rates of $100 \%$ are highlighted in bold

\begin{tabular}{|c|c|c|c|c|c|c|c|c|c|}
\hline \multirow{2}{*}{$\begin{array}{l}\text { Spawning } \\
\text { date }\end{array}$} & \multirow{2}{*}{$\begin{array}{c}\text { No. females } \\
\text { spawned }\end{array}$} & \multirow{2}{*}{$\begin{array}{l}\text { Concentration } \\
\left(\mu \mathrm{g} \mathrm{g}^{-1}\right)\end{array}$} & \multicolumn{7}{|c|}{ Marking success (\%) } \\
\hline & & & ${ }^{137} \mathrm{Ba}$ & ${ }^{136} \mathrm{Ba}$ & ${ }^{135} \mathrm{Ba}$ & ${ }^{134} \mathrm{Ba}$ & ${ }^{87} \mathrm{Sr}$ & ${ }^{86} \mathrm{Sr}$ & ${ }^{26} \mathrm{Mg}$ \\
\hline Week 1 & 4 & & 100 & 100 & 100 & 100 & 15 & 3 & 10 \\
\hline Week 2 & 0 & 2 & & & & & & & \\
\hline Week 3 & 2 & & 100 & 100 & 100 & 100 & 100 & 100 & 30 \\
\hline Week 1 & 1 & & 95 & 10 & 100 & 5 & 0 & 0 & 0 \\
\hline Week 2 & 4 & 0.2 & 100 & 98 & 100 & 90 & 5 & 5 & 8 \\
\hline Week 3 & 1 & & 100 & 100 & 100 & 100 & 10 & 0 & 0 \\
\hline Week 1 & 2 & & 95 & 0 & 100 & 0 & 0 & 0 & 0 \\
\hline Week 2 & 1 & 0.02 & 100 & 10 & 100 & 10 & 0 & 0 & 10 \\
\hline Week 3 & 1 & & 100 & 100 & 100 & 100 & 0 & 0 & 0 \\
\hline Week 1 & 0 & & 0 & 0 & 0 & 0 & 0 & 0 & 0 \\
\hline Week 2 & 4 & 0.002 & 30 & 0 & 65 & 0 & 0 & 0 & 8 \\
\hline Week 3 & 2 & & 75 & 0 & 80 & 0 & 0 & 0 & 0 \\
\hline
\end{tabular}

${ }^{87} \mathrm{Sr}$ and ${ }^{26} \mathrm{Mg}(0$ to $10 \%)$ at a concentration of $0.2 \mu \mathrm{g}$ $\mathrm{g}^{-1}$ fish or less, regardless of the number of weeks between injection and spawning. Marking success of $75 \%$ and $80 \%$ was achieved for ${ }^{135} \mathrm{Ba}$ and ${ }^{137} \mathrm{Ba}$, respectively, when spawning occurred 3 wk post injection at the lowest concentration $\left(0.002 \mu \mathrm{g} \mathrm{g}^{-1}\right.$ fish).

\section{Mark strength: maximum acquisition ratios}

Mark strength, assessed using the maximum acquisition ratios, showed that a concentration of 2 $\mu \mathrm{g} \mathrm{g}^{-1}$ fish produced the highest maximum ratios (Fig. 2, Table 3) and that maximum isotope ratios increased as the period between injection date and spawning date lengthened (Fig. 3).

Mark strength for ${ }^{134} \mathrm{Ba},{ }^{135} \mathrm{Ba},{ }^{136} \mathrm{Ba}$ and ${ }^{137} \mathrm{Ba}$ (Fig. 2) showed that the average maximum ratios were higher in the 2 and $0.2 \mu \mathrm{g}$ treatments $\left(F_{4,26}=83,88\right.$, 92,29 , respectively, $\mathrm{p}<0.001$ for all; pairwise comparisons: $2 \mu \mathrm{g}>0.2 \mu \mathrm{g}>0.02 \mu \mathrm{g}=0.002 \mu \mathrm{g}=0 \mu \mathrm{g}$, $\mathrm{p}<0.05$ for all). Ratios for the Ba isotopes ranged between 6 and 21 times greater than the threshold limit in the $2 \mu \mathrm{g}$ treatment and between 2 and 10 times greater than the threshold limit in the $0.2 \mu \mathrm{g}$ treatment (Table 3).

For ${ }^{135} \mathrm{Ba}$ and ${ }^{137} \mathrm{Ba}$, the third week had the highest average maximum ratios, but this only differed from Week 2, not Week 1 (Fig. 3; $F_{2,26}=7.2,6.4$, respectively, $\mathrm{p}<0.01$ for both; pairwise comparisons: WK3 $\geq$ $\mathrm{WK} 1=\mathrm{WK} 2, \mathrm{p}<0.05)$. For ${ }^{134} \mathrm{Ba}$ and ${ }^{136} \mathrm{Ba}$, the third week had higher average maximum ratios compared to Week 2 and Week 1 (Fig. $3 ; F_{2,26}=7.8,7.9$ respectively, $\mathrm{p}<0.01$ for both; pairwise comparisons: WK3 $>$ WK2 $=$ WK1, p < 0.05)
Average maximum ratios for mark strength for ${ }^{86} \mathrm{Sr}$ and ${ }^{87} \mathrm{Sr}$ were higher in the $2 \mu \mathrm{g}$ treatment (Fig. $2 ; F_{4,26}=29,24$ respectively, $\mathrm{p}<0.001$ for both; pairwise comparisons: $2 \mu \mathrm{g}>0.2 \mu \mathrm{g}=0.02 \mu \mathrm{g}$ $=0.002 \mu \mathrm{g}>0 \mu \mathrm{g}, \mathrm{p}<0.05$ for both), and maximum ratios were 1.1 times greater than the threshold limit (Table 3). The third week had higher average maximum ratios compared to Week 2 and Week 1 (Fig. $3 ; F_{2,26}=9.0$ and 6.4, $\mathrm{p}=0.003$ and 0.01 , respectively; pairwise comparisons: WK3 > WK2 $=$ WK1, p $<0.05$ for both).

Mark strength for ${ }^{26} \mathrm{Mg}$ showed no effect of concentration or week (Figs. $2 \& 3 ; F_{4,26}=1.8, \mathrm{p}=0.2$ and $F_{2,26}=0.6, \mathrm{p}=0.6$, respectively).

\section{Mark intensity: \% of acquisition counts above detection limit}

Mark intensity, assessed by the proportion of an otolith marked with acquisition counts above the detection limit, showed that the higher concentrations marked a greater proportion of the otolith (Fig. 4, Table 3). In addition, the proportion of an otolith marked increased as the period between injection and spawning lengthened (Fig. 5).

Acquisition counts for the Ba isotopes indicated that the $2,0.2$ and $0.02 \mu \mathrm{g}$ treatments had a greater proportion of otolith marked with enriched Ba compared to the $0.002 \mu \mathrm{g}$ treatment (Fig. $4 ; F_{3,21}=21,35,35,177$ for ${ }^{134} \mathrm{Ba},{ }^{135} \mathrm{Ba},{ }^{136} \mathrm{Ba},{ }^{137} \mathrm{Ba}$ respectively, $\mathrm{p}<0.001$ for all; for pairwise comparisons see Fig. 4). Offspring spawned $3 \mathrm{wk}$ post injection had a greater proportion of the otolith marked compared to Weeks 1 and 2 (Fig. $5 ; F_{2,21}=12,10,18,57$ for ${ }^{134} \mathrm{Ba},{ }^{135} \mathrm{Ba}^{136}{ }^{13 a},{ }^{137} \mathrm{Ba}$, 

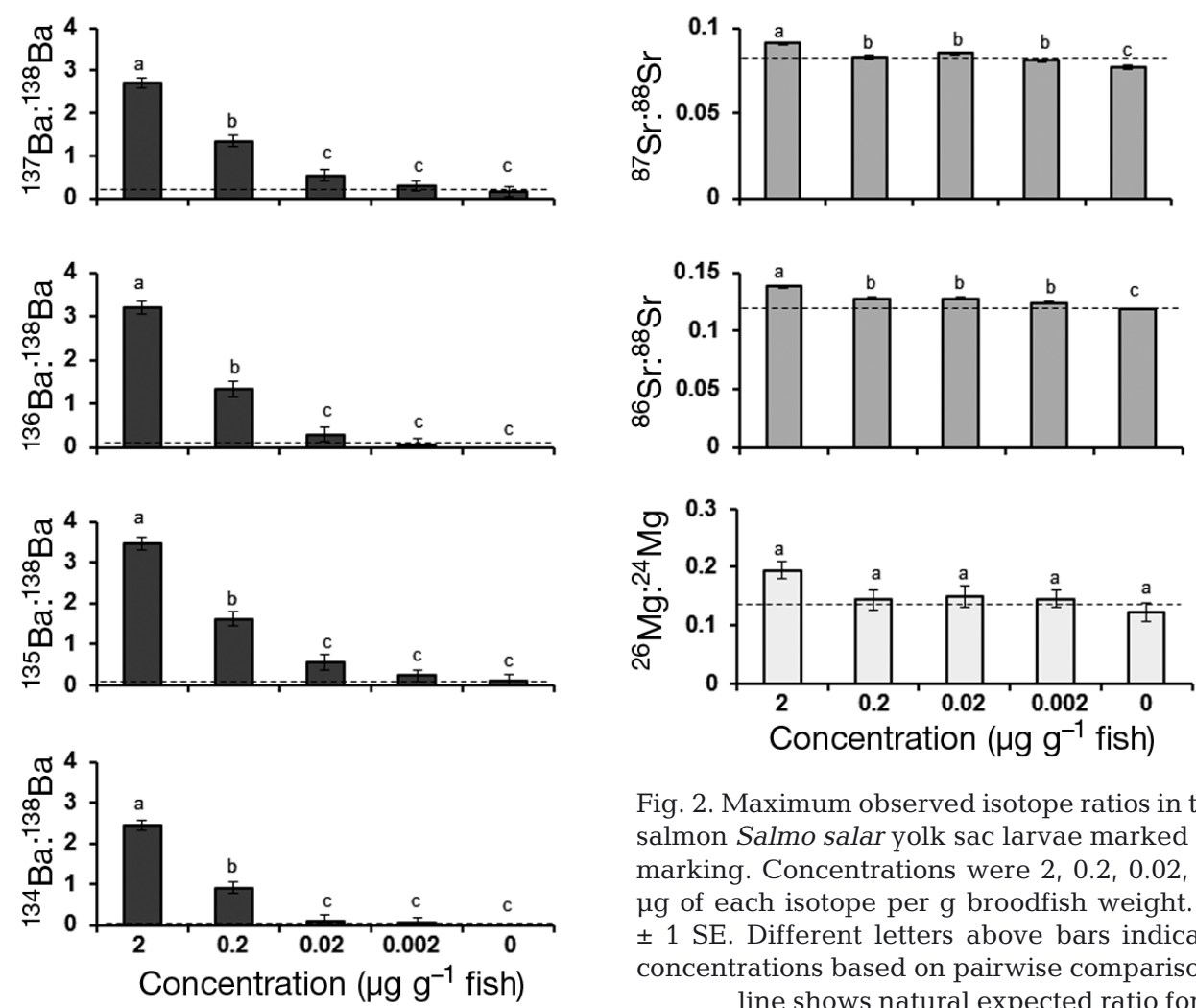

Fig. 2. Maximum observed isotope ratios in the otoliths of Atlantic salmon Salmo salar yolk sac larvae marked via transgenerational marking. Concentrations were 2, 0.2, 0.02, 0.002 and 0 (control) $\mu \mathrm{g}$ of each isotope per $\mathrm{g}$ broodfish weight. Error bars represent \pm 1 SE. Different letters above bars indicate difference among concentrations based on pairwise comparisons $(p<0.05)$. Dashed line shows natural expected ratio for each isotope

respectively, $\mathrm{p}<0.01$ for all; pairwise comparisons: $\mathrm{WK} 3>\mathrm{WK} 2=\mathrm{WK} 1, \mathrm{p}<0.05$ for all).

For ${ }^{86} \mathrm{Sr}$ and ${ }^{87} \mathrm{Sr}$, the $2 \mu \mathrm{g}$ treatment produced a greater proportion of otolith marked compared to all lower concentrations (Fig. $4 ; F_{3,21}=88$ and 134, respectively, $\mathrm{p}<0.001$ for both; for pairwise comparisons see Fig. 4). Week 3 had a greater proportion of the otolith marked compared to Weeks 1 and 2 (Fig. $5 ; F_{2,21}=50$ and 34 respectively, $\mathrm{p}<0.001$ for both; pairwise comparisons: WK3 $>$ WK2 $=$ WK1, p < 0.05 for both).
The number of acquisition counts above the detection limit for ${ }^{26} \mathrm{Mg}$ was insufficient to justify conducting mark intensity analysis on the proportion of otolith marked.

\section{Broodstock health, hatchery mortality, larval deformities and condition at harvest}

Of the 30 females injected, 3 fish were unsuccessfully spawned. These consisted of 1 fish that

Table 3. Comparison of isotope mark strength and intensity. Strength is the number of times the maximum isotope ratio measured in a marked otolith is greater than the threshold limit. Intensity is the percentage of the otolith marked with an isotope ratio greater than the threshold limit. Shading indicates the minimum number of weeks required between injection date and spawning date to reach $100 \%$ marking success for each isotope (dark grey: 1 wk, medium grey: 2 wk; light grey: 3 wk; no shading: $100 \%$ marking success was not achieved)

\begin{tabular}{|c|c|c|c|c|c|c|c|c|}
\hline \multirow[b]{2}{*}{ Isotope } & \multicolumn{2}{|c|}{$-2\left(\mu g^{-1}\right) \longleftarrow$} & \multicolumn{2}{|c|}{$-0.2\left(\mu \mathrm{g} \mathrm{g}^{-1}\right) \longleftarrow$} & \multicolumn{2}{|c|}{$-0.02\left(\mu \mathrm{g} \mathrm{g}^{-1}\right) \longleftarrow$} & \multicolumn{2}{|c|}{$-0.002\left(\mu \mathrm{g} \mathrm{g}^{-1}\right)-$} \\
\hline & Strength & Intensity $(\%)$ & Strength & Intensity (\%) & Strength & Intensity (\%) & Strength & Intensity (\%) \\
\hline${ }^{137} \mathrm{Ba}$ & 11.0 & 99.5 & 5.5 & 83.7 & 2.8 & 71.2 & 1.2 & 17.1 \\
\hline${ }^{136} \mathrm{Ba}$ & 7.6 & 95.5 & 3.2 & 61.7 & 2.3 & 35.3 & 0 & 0 \\
\hline${ }^{135} \mathrm{Ba}$ & 21.5 & 99.8 & 10.0 & 89.9 & 4.6 & 79.8 & 1.5 & 36.2 \\
\hline${ }^{134} \mathrm{Ba}$ & 6.2 & 92.3 & 2.3 & 55.4 & 2.0 & 33.6 & 0 & 0 \\
\hline${ }^{87} \mathrm{Sr}$ & 1.1 & 42.6 & 0 & 0 & 0 & 0 & 0 & 0 \\
\hline${ }^{86} \mathrm{Sr}$ & 1.1 & 36.9 & 1.0 & 0.8 & 0 & 0 & 0 & 0 \\
\hline
\end{tabular}



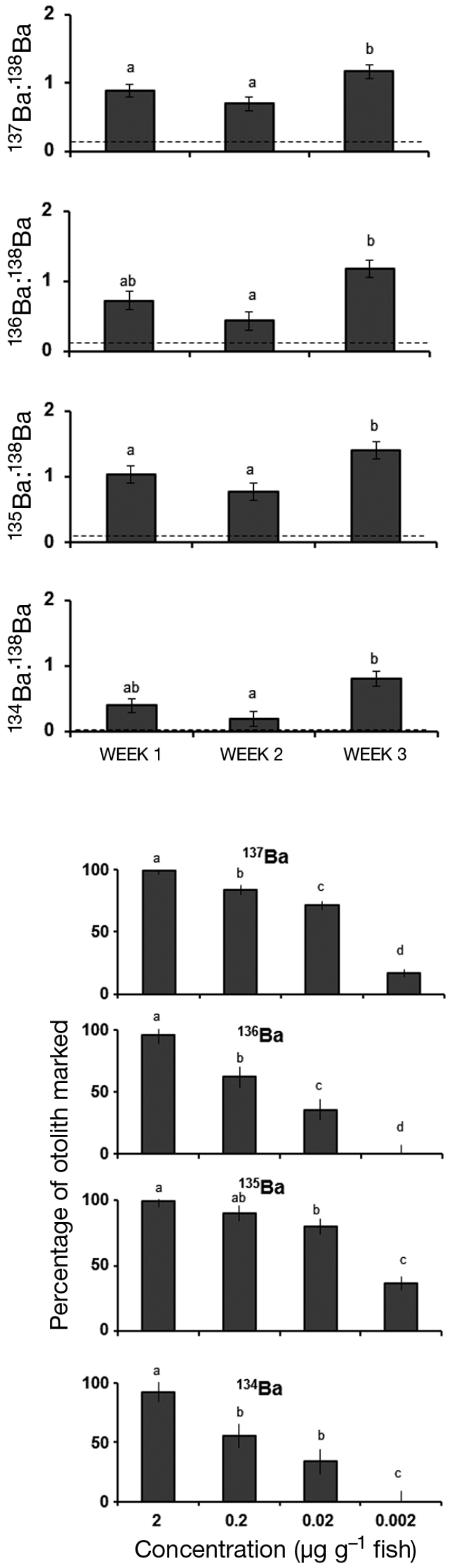
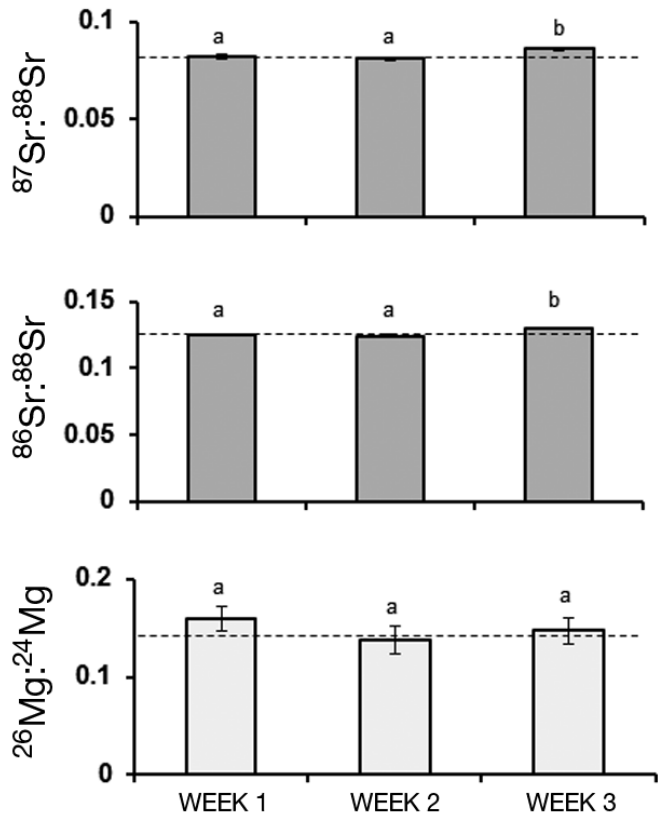

Fig. 3. Maximum observed isotope ratios in the otoliths of Atlantic salmon Salmo salar yolk sac larvae marked via transgenerational marking categorized by number of weeks between injection date and spawning date. Error bars represent $\pm 1 \mathrm{SE}$. Different letters above bars indicate differences among concentrations based on pairwise comparisons $(\mathrm{p}<0.05)$. Dashed line shows natural expected ratio for each isotope
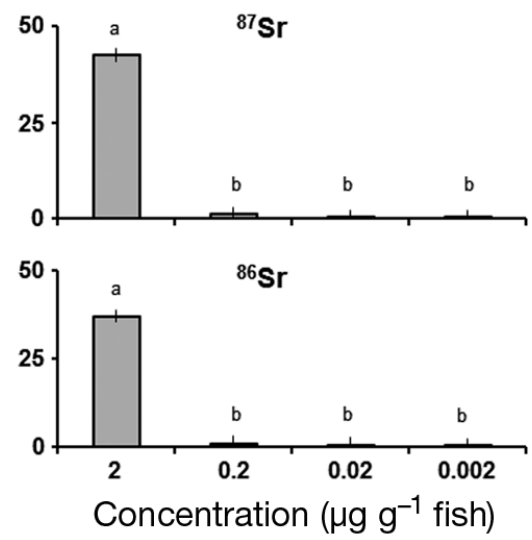

Fig. 4. Percentage of an otolith marked with enriched barium isotopes between the edge and the core of Atlantic salmon Salmo salar yolk sac larval otoliths marked via transgenerational marking. Concentrations were $2,0.2,0.02,0.002 \mu \mathrm{g}$ of each isotope per $\mathrm{g}$ broodfish weight. Error bars represent $\pm 1 \mathrm{SE}$. Different letters above bars indicate differences among concentrations based on pairwise comparisons $(\mathrm{p}<0.05)$ 


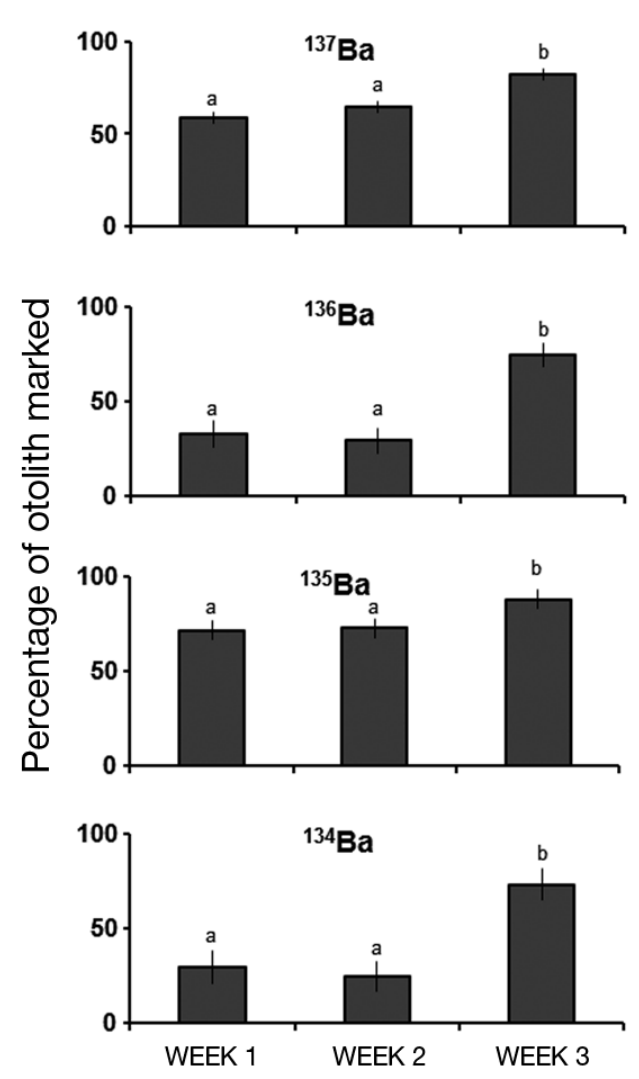

died $10 \mathrm{~d}$ after injection for reasons that were unknown, a second fish having overripe eggs due to being stripped too late, and the third individual not reaching spawning ripeness in the time frame of egg collection (within $6 \mathrm{wk}$ post injection). All other females in the experiment produced viable eggs, although there was some variation in the degree of egg ripeness when spawned. Offspring mortality between egg fertilisation and first feeding stage (mean $\pm \mathrm{SE}$ ) averaged $15.7 \pm 3 \%$ per egg batch, and there was no treatment effect of isotope enrichment $\left(F_{4,26}=1.2, \mathrm{p}=0.4\right)$. Yolk sac larval deformities that we observed between hatching and first feeding averaged $0.25 \pm 0.07 \%$ per egg batch, with no treatment effect of isotope enrichment $\left(F_{4,26}=0.5, \mathrm{p}=0.7\right)$. Fish harvested at $2.25 \mathrm{yr}$ post hatch (weight: $3.79 \pm 0.02 \mathrm{~kg}$, fork length: $62.9 \pm 2.5 \mathrm{~cm}$, condition factor $k$ : $1.39 \pm$ 0.06) showed no significant difference in length, weight or condition among treatments (weight: $F_{4,26}$ $=0.88, \mathrm{p}=0.5 ;$ fork length: $F_{4,26}=0.81, \mathrm{p}=0.5 ; \mathrm{k}$ : $F_{4,26}=1.59, \mathrm{p}=0.2$ ). Mortality per treatment during the sea cage stage averaged $8 \pm 0.5 \%$, with no significant difference among treatments $\left(F_{4,26}=\right.$ $1.79, \mathrm{p}=0.9$ ).
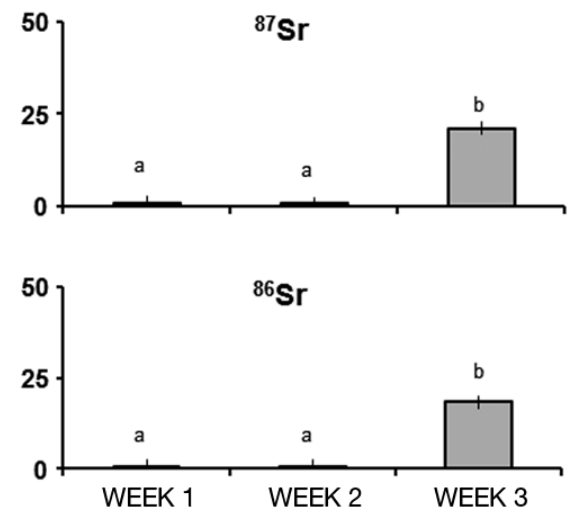

Fig. 5. Percentage of an otolith marked with enriched barium isotopes between the edge and the core of Atlantic salmon Salmo salar yolk sac larval otoliths marked via transgenerational marking categorized by number of weeks between injection date and spawning date. Error bars represent \pm 1 SE. Different letters above bars indicate differences among concentrations based on pairwise comparisons $(\mathrm{p}<0.05)$

\section{DISCUSSION}

We have demonstrated that producing unique isotopic fingerprint marks in the otoliths of Atlantic salmon larvae via transgenerational marking is highly successful with Ba- and Sr-enriched stable isotopes. This means it is possible to mass mark farmed Atlantic salmon at the earliest possible point in the life cycle, prior to spawning. Ensuring 100\% marking success is dependent on the concentration of enriched isotope used and the length of time between injection date and spawning date.

\section{Marking success}

A 6-marker fingerprint with $100 \%$ marking success was achieved using a combination of $4 \mathrm{Ba}$ - and $2 \mathrm{Sr}-$ enriched stable isotopes in the $2 \mu \mathrm{g} \mathrm{g}^{-1}$ broodfish treatment when injection date and spawning date were at least $3 \mathrm{wk}$ apart. This is the first reported successful 6-mark isotope combination using the transgenerational marking technique. Only 1 other study has successfully marked fish with a 6-isotope combination (Warren-Myers et al. 2015a), but marks were 
delivered by an injection of stable isotopes directly into salmon parr, not via broodstock. We achieved $100 \%$ marking success for concentrations lower than $2 \mu \mathrm{g} \mathrm{g}^{-1}$ female when using the $4 \mathrm{Ba}$ isotopes, but not the $2 \mathrm{Sr}$ isotopes, with all Ba isotopes achieving $100 \%$ marking success at $0.02 \mu \mathrm{g} \mathrm{g}^{-1}$ female when injection date and spawning date were at least $3 \mathrm{wk}$ apart. Ba concentrations as low as $0.5 \mu \mathrm{g} \mathrm{g}^{-1}$ female have been successful in saltwater species (Thorrold et al. 2006, Williamson et al. 2009b) and $0.3 \mu \mathrm{g} \mathrm{g}^{-1}$ female in freshwater species (Huelga-Suarez et al. 2013), yet these are 15 to 25 times higher than we used in this study to achieve $100 \%$ marking success. However, compared to our study, the minimum time between injection and spawning was generally shorter in saltwater species (3 d: Thorrold et al. 2006; $13 \mathrm{~d}$ : Williamson et al. 2009b) and longer in freshwater species (1 to 2 mo: Huelga-Suarez et al. 2013). Marking success with ${ }^{26} \mathrm{Mg}$ was poor (0 to $30 \%$ ) and hence it is unsuitable for isotope marking. Similar results have been reported for marking Atlantic salmon via vaccination (Warren-Myers et al. 2014, 2015a), egg immersion (Warren-Myers et al. 2015b) and larval immersion (de Braux et al. 2014), which suggest that the delivery method is not the reason for poor marking success with ${ }^{26} \mathrm{Mg}$.

\section{Mark strength and intensity}

${ }^{135} \mathrm{Ba}$ produced the strongest (maximum ratio) and most intense (proportion of an otolith marked) tags (Table 3). On average, $80 \%$ of acquisitions in the otolith were marked with ${ }^{135} \mathrm{Ba}$ at the lowest successful concentration $\left(0.02 \mu \mathrm{g} \mathrm{g}^{-1}\right.$ female) with a maximum value 4.6 times higher than the threshold limit. ${ }^{137} \mathrm{Ba}$ produced marks of similar strength and intensity with $71 \%$ of acquisitions marked and an average maximum value 2.8 times above the threshold limit. ${ }^{137} \mathrm{Ba}$ is the most commonly used Ba isotope for marking fish otoliths (Thorrold et al. 2006, Munro et al. 2009, Cuif et al. 2014), and ${ }^{135} \mathrm{Ba}$ less so (Almany et al. 2007, Williamson et al. 2009b), yet our results suggest that ${ }^{135} \mathrm{Ba}$ has the potential to produce slightly stronger marks than ${ }^{137} \mathrm{Ba}$, potentially due to differences in purity of the 2 enriched isotopes used $\left({ }^{137} \mathrm{Ba}\right.$ : $81.7 \%$ vs. ${ }^{135} \mathrm{Ba}$ : $93.4 \%$; Oak Ridge National Laboratory; www.ornl.gov).

${ }^{134} \mathrm{Ba}$ and ${ }^{136} \mathrm{Ba}$ mark strength and intensity were $\sim 50 \%$ lower compared to ${ }^{135} \mathrm{Ba}$ and ${ }^{137} \mathrm{Ba}$ in the $0.02 \mathrm{\mu g} \mathrm{g}^{-1}$ concentration (Table 3), likely due to the higher detection limits for these isotopes resulting from isobaric interference from $\mathrm{Xe}$ in the carrier gases. On average, 34 and $35 \%$ of acquisitions in the otoliths were marked with ${ }^{134} \mathrm{Ba}$ and ${ }^{136} \mathrm{Ba}$, respectively, with maximum values 2 and 2.3 times higher than the threshold limits. Although strength and intensity were $\sim 50 \%$ lower, marks created with ${ }^{134} \mathrm{Ba}$ and ${ }^{136} \mathrm{Ba}$ were clearly definable at a concentration of $0.02{\mu g ~ g^{-1}}$ female when the timing between injection and spawning surpassed $3 \mathrm{wk}$ and therefore should be highly useful for creating fingerprint combinations using 1, 2, 3 or 4 Ba isotopes. Prior to this study, neither of these isotopes had been tested or demonstrated to be $100 \%$ successful in marking otoliths using transgenerational marking. However, WarrenMyers et al. (2015a) successfully used ${ }^{136} \mathrm{Ba}$ and ${ }^{134} \mathrm{Ba}$ mixed with a vaccine and delivered via injection in Atlantic salmon parr and produced slightly higher mark strength values (3.6 times the relative threshold limit for both). In addition, Woodcock et al. (2011a) achieved $93 \%$ marking success with ${ }^{136} \mathrm{Ba}$ in golden perch Macquaria ambigua using a larval immersion technique, but reported neither mark strength nor intensity.

${ }^{86} \mathrm{Sr}$ and ${ }^{87} \mathrm{Sr}$ produced well defined marks in the otoliths of offspring that came from broodstock females injected with a concentration of $2 \mu \mathrm{g} \mathrm{g}^{-1}$ female and spawned 3 wk post injection. Mark strength maximum values were 1.1 times higher than the threshold limit for both ${ }^{86} \mathrm{Sr}$ and ${ }^{87} \mathrm{Sr}$ and 37 to $43 \%$ of acquisitions in the otoliths were marked with ${ }^{86} \mathrm{Sr}$ and ${ }^{87} \mathrm{Sr}$, respectively. Marking success with ${ }^{86} \mathrm{Sr}$ and ${ }^{87} \mathrm{Sr}$ at a concentration of $2 \mu \mathrm{g} \mathrm{g}^{-1}$ female has not been demonstrated prior to this study using LA-ICPMS detection methods. However, $100 \%$ success has been achieved with ${ }^{87} \mathrm{Sr}$ at a concentration of $20 \mu \mathrm{g}$ $\mathrm{g}^{-1}$ female (Starrs et al. 2014b). Relative to the concentration of $0.02 \mu \mathrm{g} \mathrm{g}^{-1}$ female of all $4 \mathrm{Ba}$ isotopes required to inject $10 \mathrm{~kg}$ Atlantic salmon broodstock to ensure successful marking of offspring, $2 \mu \mathrm{g} \mathrm{g}^{-1}$ female for $\mathrm{Sr}$ isotopes is high. Sr isotopes are therefore less financially feasible for mass marking programs. Sr isotopes may be more suitable if applied to smaller sized species (e.g. eastern rainbowfish Melanotaenia splendida; Starrs et al. 2014b) or by alternate delivery methods, such as immersion (Munro et al. 2008, Smith \& Whitledge 2011, deBraux et al. 2014).

\section{Broodstock health, hatchery mortality, larval deformities and condition at harvest}

Injecting broodstock with enriched stable isotopes had no effect on spawning success or broodstock sur- 


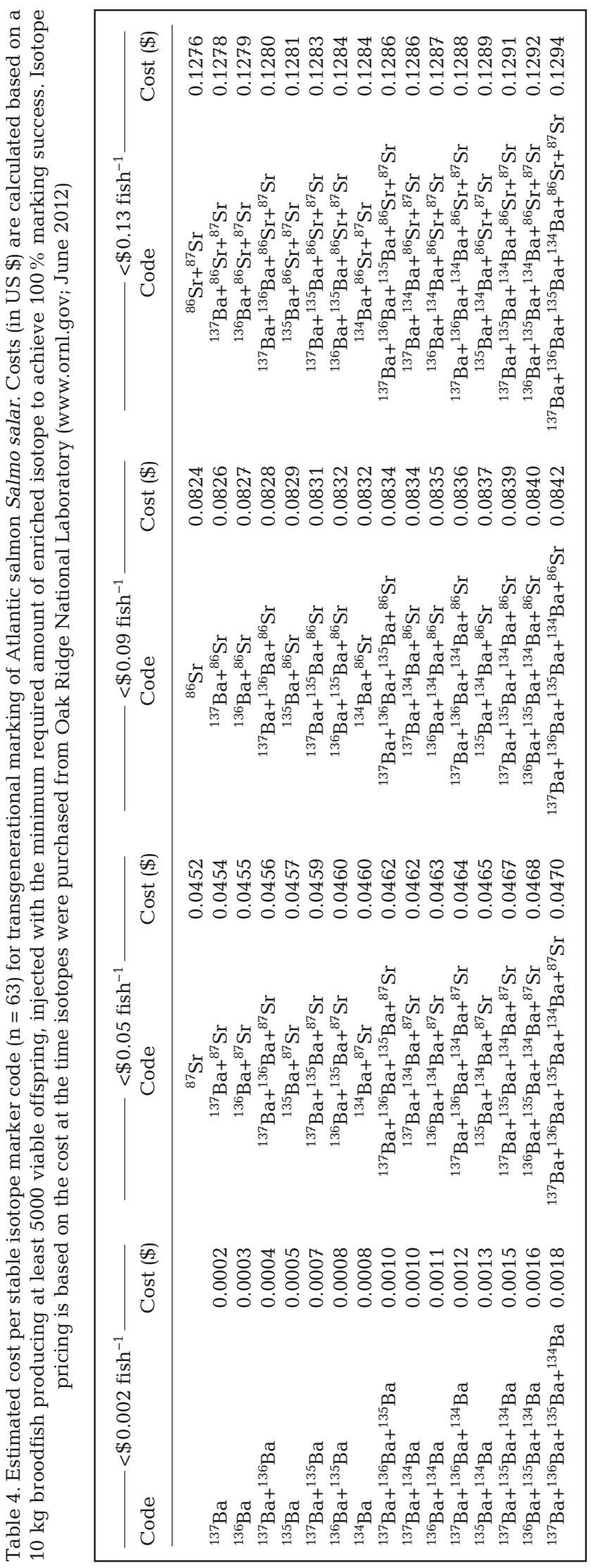

vival to spawning. However, when eggs were stripped, some internal bleeding in the abdominal cavity had occurred around the injection site in some females in both treatment and control fish. Smaller injection volumes may help prevent this from occurring, and should be tested in the future, particularly as the process of injection has been reported to kill broodfish in other species (e.g. Starrs et al. 2014b). Offspring of all successfully spawned females (27 of 30) showed no effect of isotope marking on egg survival or larval deformity rates, which is consistent with other studies that have marked with stable isotopes at concentrations equivalent to $2 \mu \mathrm{g} \mathrm{g} \mathrm{g}^{-1}$ female or less (Thorrold et al. 2006, Cuif et al. 2014, WarrenMyers et al. 2015b). No effect of marking on harvest size fish was found, which is consistent with results observed in fish that have been vaccinated with stable isotopes and grown to $5 \mathrm{~kg}$ (Warren-Myers et al. 2015a). Based on our results and previous research (Williamson et al. 2009a), transgenerational marking with stable isotopes of $\mathrm{Ba}$ and $\mathrm{Sr}$ is a safe, effective method for mass marking farmed fish.

\section{Transgenerational marking as a mass marking tool}

Mass marking millions of fish can be an expensive exercise, hence quick, accurate and cost-effective techniques that instantly batch mark numerous fish are preferred. Here, we have shown that transgenerational marking with enriched stable isotopes is another useful tool for mass marking salmon offspring prior to spawning in commercial hatcheries with 63 unique codes possible (Table 4). Marks using Ba isotopes are cheaper to apply (US\$0.0002-0.002 $\mathrm{fish}^{-1}$ ) compared to Sr isotopes (US\$0.05-0.13 fish ${ }^{-1}$ ), but $\mathrm{Sr}$ isotopes may still be useful if used on small numbers of broodfish. The LA-ICP-MS cost to detect marks using spot ablation was approximately US\$15-20 otolith ${ }^{-1}$. For the identification of escaped farmed fish, this may be considered expensive relative to the marking costs. However, the cost to analyse hundreds of fish at US\$20 otolith ${ }^{-1}$ is small relative to the cost to apply marks to hundreds of millions of farmed fish. Whether further otolith preparation (e.g. sectioning) is required to accurately detect the marks in adult salmon otoliths must be confirmed to fully validate the method as a marker approach for application at an industry scale.

To date, transgenerational marking with enriched stable isotopes has been validated in 13 species (Table 5), including freshwater, diadromous and marine fish. Both Sr- and Ba-enriched isotopes work well 
for freshwater species, yet $\mathrm{Sr}$ is not as successful as Ba for marine species. This may be because the natural abundance of $\mathrm{Sr}$ increases with salinity (Walther \& Limburg 2012). Hence, the higher abundance of $\mathrm{Sr}$ in marine waters may be reflected in the maternal Sr levels in marine fish, or fish with a marine growth phase, which mask any effects of the enriched Sr isotope introduced. Broodstock in this study were transferred from seawater cages 2 mo prior to spawning and held in freshwater tanks buffered with $0.7 \% \mathrm{NaCl}$ thereafter, which may have reduced the seawater Sr signal. However, determining whether this occurred would require daily or weekly measurements of total Sr levels in broodfish for several months prior to spawning.

Analysis of all transgenerational marking studies with enriched stable isotopes conducted to date reveals that $\mathrm{Ba}$ isotopes have been the most successful across all fish species tested (Table 5). For Atlantic salmon, this is also the case for different delivery methods that have tested isotope marking across a range of life history stages, for example; bathing of freshly fertilised eggs (WarrenMyers et al. 2015b), immersion of yolk sac larvae (de-Braux et al. 2014) or injection of parr (Warren-Myers et al. 2015a). In Atlantic salmon, isotopes of $\mathrm{Ba}$ produce strong, easily identifiable marks at concentrations 100 times lower than $\mathrm{Sr}$ isotopes and therefore are the most suitable and cost-effective isotopes to use for mass marking farmed fish. Transgenerational marking with $\mathrm{Ba}$ isotopes is another successful method to effectively mass mark fish that pinpoints the prespawning stage in the production life cycle.

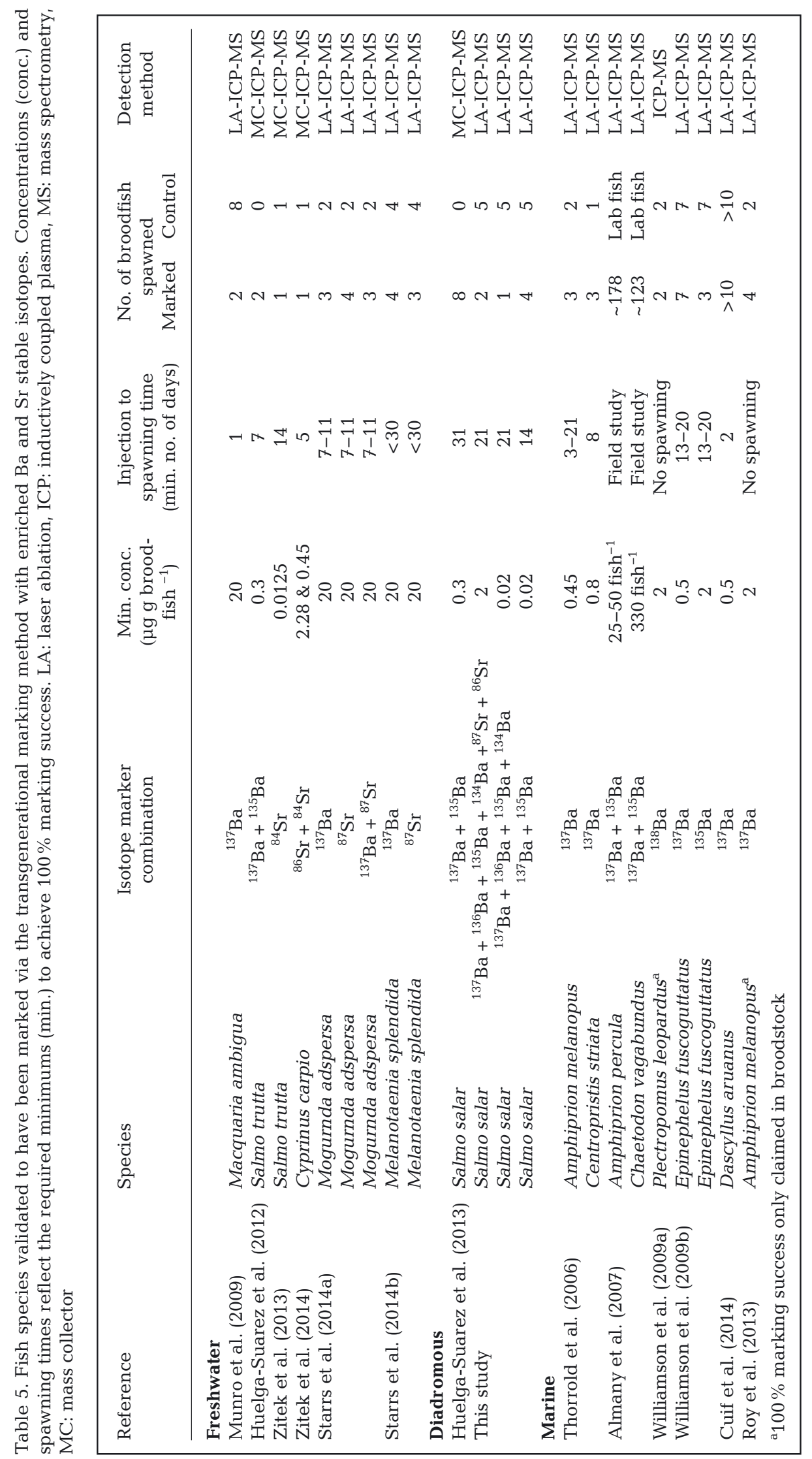


Acknowledgements. We thank Lise Dyrhovden and the technical staff from the Matre Aquaculture Research Station for their animal husbandry expertise in rearing the salmon over the $2.5 \mathrm{yr}$ of the experiment, and Alan Greig from the School of Earth Sciences, University of Melbourne, who assisted with LA-ICP-MS analyses. Funding was provided by the Norwegian Fisheries and Aquaculture Research Fund (project no. 900710).

\section{LITERATURE CITED}

Almany GR, Berumen ML, Thorrold SR, Planes S, Jones GP (2007) Local replenishment of coral reef fish populations in a marine reserve. Science 316:742-744

> Barbee NC, Swearer SE (2007) Characterizing natal source population signatures in the diadromous fish Galaxias maculatus, using embryonic otolith chemistry. Mar Ecol Prog Ser 343:273-282

Cuif M, Keller F, Chateau O, Kaplan DM, Labonne M, Lett C, Vigliola L (2014) Evaluation of transgenerational isotope labeling of embryonic otoliths in a coral reef damselfish with single and repeated injections of enriched ${ }^{137}$ Barium. J Exp Mar Biol Ecol 459:151-159

> de Braux E, Warren-Myers F, Dempster T, Fjelldal PG, Hansen T, Swearer SE (2014) Osmotic induction improves batch marking of larval fish otoliths with enriched stable isotopes. ICES J Mar Sci 71:2530-2538

FitzGerald JL, Sheehan TF, Kocik JF (2004) Visibility of visual implant elastomer tags in Atlantic salmon reared for two years in marine net-pens. N Am J Fish Manag 24: 222-227

> Fleming IA, Hindar K, Mjølnerød IB, Jonsson B, Balstad T, Lamberg A (2000) Lifetime success and interactions of farm salmon invading a native population. Proc R Soc Lond B Biol Sci 267:1517-1523

Glover KA (2010) Forensic identification of fish farm escapees: the Norwegian experience. Aquacult Environ Interact 1:1-10

Glover KA, Sørvik AGE, Karlsbakk E, Zhang Z, Skaala Ø (2013) Molecular genetic analysis of stomach contents reveals wild Atlantic cod feeding on Piscine Reovirus (PRV) infected Atlantic salmon originating from a commercial fish farm. PLoS ONE 8:e60924

> Hindar K, Fleming IA, McGinnity P, Diserud O (2006) Genetic and ecological effects of salmon farming on wild salmon: modelling from experimental results. ICES J Mar Sci 63:1234-1247

Huelga-Suarez G, Moldovan M, Garcia-Valiente A, GarciaVazquez E, Garcia Alonso JI (2012) Individual-specific transgenerational marking of fish populations based on a barium dual-isotope procedure. Anal Chem 84:127-133

> Huelga-Suarez G, Fernández B, Moldovan M, García Alonso JI (2013) Detection of transgenerational barium dual-isotope marks in salmon otoliths by means of LA-ICP-MS. Anal Bioanal Biochem 405:2901-2909

Hutchings JA, Fraser DJ (2008) The nature of fisheries- and farming- induced evolution. Mol Ecol 17:294-313

Jensen $\varnothing$, Dempster T, Thorstad EB, Uglem I, Fredheim A (2010) Escapes of fishes from Norwegian sea-cage aquaculture: causes, consequences and prevention. Aquacult Environ Interact 1:71-83

> McGinnity P, Prodöhl P, Ferguson A, Hynes R and others (2003) Fitness reduction and potential extinction of wild populations of Atlantic salmon, Salmo salar, as a result of interactions with escaped farm salmon. Proc R Soc Lond B Biol Sci 270:2443-2450

- Mohler JW (2003) Producing fluorescent marks on Atlantic salmon fin rays and scales with calcein via osmotic induction. N Am J Fish Manag 23:1108-1113

Munro AR, Gillanders BM, Elsdon TS, Crook DA, Sanger AC (2008) Enriched stable isotope marking of juvenile golden perch (Macquaria ambigua) otoliths. Can J Fish Aquat Sci 65:276-285

> Munro AR, Gillanders BM, Thurstant S, Crook DA, Sanger AC (2009) Transgenerational marking of freshwater fishes with enriched stable isotopes: a tool for fisheries management and research. J Fish Biol 75:668-684

Ricker WE (1975) Computation and interpretation of biological statistics of fish populations. Bull Fish Res Board Can 191:1-382

> Roy AS, Frisch AJ, Syms C, Thorrold SR, Jones GP (2013) Retention of a transgenerational marker $\left({ }^{137}\right.$ Barium) in tissues of adult female anemonefish and assessment of physiological stress. Environ Biol Fishes 96:459-466

Smith KT, Whitledge GW (2011) Evaluation of a stableisotope labelling technique for mass marking fin rays of age-0 lake sturgeon. Fish Manag Ecol 18:168-175

Starrs D, Davis JT, Schlaefer J, Ebner BC, Eggins SM, Fulton CJ (2014a) Maternally transmitted isotopes and their effects on larval fish: a validation of dual isotopic marks within a meta-analysis context. Can J Fish Aquat Sci 71: 387-397

Starrs D, Ebner BC, Eggins S, Fulton CJ (2014b) Longevity in maternal transmission of isotopic marks in a tropical freshwater rainbowfish and the implications for offspring morphology. Mar Freshw Res 65:400-408

Taylor MD, Fielder DS, Suthers IM (2005) Batch marking of otoliths and fin spines to assess the stock enhancement of Argyrosomus japonicus. J Fish Biol 66:1149-1162

> Thorrold SR, Jones GP, Planes S, Hare JA (2006) Transgenerational marking of embryonic otoliths in marine fishes using barium stable isotopes. Can J Fish Aquat Sci 63: 1193-1197

Toledo-Guedes K, Sánchez-Jerez P, Mora-Vidal J, Girard D, Brito A (2012) Escaped introduced sea bass (Dicentrarchus labrax) infected by Sphaerospora testicularis (Myxozoa) reach maturity in coastal habitats off Canary Islands. Mar Ecol 33:26-31

> Vander Haegen GE, Blankenship HL, Hoffmann A, Thompson DA (2005) The effects of adipose fin clipping and coded wire tagging on the survival and growth of spring chinook salmon. N Am J Fish Manag 25:1161-1170

Walther BD, Limburg KE (2012) The use of otolith chemistry to characterize diadromous migrations. J Fish Biol 81: 796-825

- Warren-Myers F, Dempster T, Fjelldal PG, Hansen T, Jensen AJ, Swearer SE (2014) Stable isotope marking of otoliths during vaccination: a novel method for mass marking fish. Aquacult Environ Interact 5:143-154

> Warren-Myers F, Dempster T, Fjelldal PG, Hansen T, Swearer SE (2015a) An industry-scale mass marking technique for tracing farmed fish escapees. PLoS ONE 10:e0118594

- Warren-Myers F, Dempster T, Fjelldal PG, Hansen T, Swearer SE (2015b) Immersion during egg swelling results in rapid uptake of stable isotope markers in salmonid otoliths. Can J Fish Aquat Sci 72:722-727

Williamson DH, Jones GP, Thorrold SR, Frisch AJ (2009a) Transgenerational marking of marine fish larvae: stable- 
isotope retention, physiological effects and health issues. J Fish Biol 74:891-905

Williamson DH, Jones GP, Thorrold SR (2009b) An experimental evaluation of transgenerational isotope labelling in a coral reef grouper. Mar Biol 156:2517-2525

Woodcock SH, Gillanders BM, Munro AR, McGovern F, Crook DA, Sanger AC (2011a) Using enriched stable isotopes of barium and magnesium to batch mark otoliths of larval golden perch (Macquaria ambigua, Richardson). Ecol Freshw Fish 20:157-165

Woodcock SH, Gillanders BM, Munro AR, Crook DA, Sanger AC (2011b) Determining mark success of 15 com-

Editorial responsibility: Pablo Sánchez Jerez, Alicante, Spain binations of enriched stable isotopes for the batch marking of larval otoliths. N Am J Fish Manag 31:843-851

Woodcock SH, Grieshaber CA, Walther BD (2013) Dietary transfer of enriched stable isotopes to mark otoliths, fin rays and scales. Can J Fish Aquat Sci 70:1-4

Zitek A, Irrgeher J, Kletzl M, Weismann T, Prohaska T (2013) Transgenerational marking of brown trout Salmo trutta f.f., using an ${ }^{84}$ Sr spike. Fish Manag Ecol 20:354-361

Zitek A, Irrgeher J, Cervicek M, Horsky M, Kletzl M, Weismann T, Prohaska T (2014) Individual-specific transgenerational marking of common carp Cyprinus carpio, L., using ${ }^{86} \mathrm{Sr} /{ }^{84} \mathrm{Sr}$ double spikes. Mar Freshw Res 65:978-986

Submitted: April 20, 2015; Accepted: June 29, 2015

Proofs received from author(s): August 6, 2015 